\title{
Pengembangan E-LKPD fisika berbasis inkuiri terbimbing pada materi gerak lurus untuk peserta didik Kelas X SMA
}

\author{
Via Aksari \\ Pendidikan Fisika, Universitas Sarjanawiyata Tamansiswa, Indonesia \\ Surat-e: viaapsari26@gmail.com \\ Widodo Budhi \\ Pendidikan Fisika, Universitas Sarjanawiyata Tamansiswa, Indonesia \\ Surat-e: budhi@ustjogja.ac.id

\section{Daimul Hasanah} \\ Pendidikan Fisika, Universitas Sarjanawiyata Tamansiswa, Indonesia \\ Surat-e: hasanah@ustjogja.ac.id
}

\begin{abstract}
Abstrak. Penelitian ini bertujuan untuk menghasilkan E-LKPD Fisika Berbasis Inkuiri Terbimbing pada Materi Gerak Lurus untuk Peserta Didik Kelas X SMAN 1 Parittiga; mengetahui kelayakan E-LKPD berdasarkan penilaian dari ahli dan praktisi; serta mengetahui respon peserta didik terhadap E-LKPD yang telah dikembangkan. Penelitian ini termasuk jenis penelitian dan pengembangan; dengan mengadopsi model penelitian dan pengembangan menurut Sugiyono yang terdiri atas lima tahapan dari sepuluh tahapan penelitian dan pengembangan menurut Sugiyono, antara lain potensi dan masalah, mengumpulkan informasi, desain produk, validasi desain, perbaikan desain. Instrumen yang digunakan antara lain angket penilaian kelayakan E-LKPD dan angket respon peserta didik terhadap E-LKPD. Teknik analisis data yang digunakan antara lain indeks V Aiken dan statistika deskriptif (persentase frekuensi). Hasil penelitian ini antara lain: telah dihasilkan E-LKPD Fisika Berbasis Inkuiri Terbimbing dengan mengintegrasikan berbagai aplikasi, yakni aplikasi Phet dan video tutorial; kelayakan E-LKPD termasuk dalam kategori tinggi; serta respon peserta didik terhadap ELKPD termasuk dalam kategori positif.
\end{abstract}

Kata kunci: E-LKPD fisika, inkuiri terbimbing, materi gerak lurus.

\begin{abstract}
This study aims to produce E-LKPD Physics Based on Guided Inquiry on Straight Motion Material for Class X Students of SMAN 1 Parittiga; know the feasibility of E-LKPD based on the assessment of experts and practitioners; as well as knowing the response of students to the E-LKPD that has been developed. This research includes the type of research and development; by adopting the research and development model according to Sugiyono which consists of five stages from ten stages of research and development according to Sugiyono, including potential and problems, gathering information, product design, design validation, design improvement. The instruments used included an E-LKPD feasibility assessment questionnaire and a student response questionnaire to E-LKPD. The data analysis techniques used include the Aiken V index and descriptive statistics (frequency percentage). The results of this study include: E-LKPD Physics Based on Guided Inquiry by integrating some applications such as Phet application and video tutorial; the eligibility of the E-LKPD is included in the high category; as well as students' responses to the E-LKPD included in the positive category.
\end{abstract}

Keywords: E-LKPD physics, guided inquiry, straight motion. 


\section{Pendahuluan}

Corona virus disease 2019 atau Covid-19 telah mengubah kehidupan manusia di seluruh dunia, baik dalam bidang ekonomi, pariwisata, industri, maupun pendidikan. Selama masa pandemi Covid-19, manusia menggunakan berbagai aplikasi informasi untuk dapat menjalankan kegiatan dari rumah. Untuk mendukung keberlangsungan dunia pendidikan agar tetap berjalan optimal selama masa pandemi Covid-19, pemerintah mengeluarkan kebijakan baru, yaitu Work from Home (WfH). Peserta didik belajar dari rumah dengan memanfaatkan aplikasi pembelajaran yang digunakan oleh guru untuk memfasilitasi proses pembelajaran secara daring dari rumah.

Kurikulum 2013 menekankan pendidikan berpusat pada peserta didik. Peserta didik dituntut untuk lebih aktif dalam proses pembelajaran dan guru hanya berperan sebagai fasilitator. Sejalan dengan tujuan dari kurikulum 2013, pendidikan di Indonesia perlu melakukan pengembangan pola pembelajaran di masa pandemi Covid-19 saat ini. Salah satunya melalui pola pembelajaran jarak jauh (PJJ). Dalam pola pembelajaran jarak jauh, peserta didik dituntut lebih aktif dalam proses pembelajaran. Selain itu, peran guru dalam proses pembelajaran hanya sebagai fasilitator saja dan guru bukan satu-satunya sumber belajar yang utama bagi peserta didik. Kenyataan yang terjadi di SMA N 1 Parittiga, peserta didik masih menjadikan guru sebagai sumber utama kegiatan belajar. Dalam proses pembelajaran fisika, guru masih menjadi pusat pembelajaran, baik secara luring di kelas maupun secara daring melalui aplikasi pembelajaran. Proses pembelajaran fisika yang dilakukan oleh guru juga masih monoton yaitu hanya memfokuskan pada penambahan pengetahuan peserta didik sehingga berdampak pada motivasi belajar fisika peserta didik relatif rendah.

Hasil wawancara dengan guru mata pelajaran fisika di SMA N 1 Parittiga diperoleh informasi bahwa dalam proses pembelajaran fisika, guru belum menggunakan model pembelajaran inkuiri terbimbing, guru hanya memfokuskan pada pemberian materi pelajaran kepada peserta didik sehingga peserta didik menjadi pasif dalam proses pembelajaran fisika, padahal pembelajaran inkuri terbimbing dipandang mampu memfasilitasi peserta didik mengkonstruksi pengetahuannya melalui berbagai macam aktivitas eksperimen ataupun penemuan. Sementara itu, hasil wawancara dengan beberapa peserta didik menyatakan bahwa peserta didik kurang memiliki minat terhadap pelajaran fisika karena pelajaran tersebut memiliki banyak persamaan dan sulit memahami konsepnya. Permasalahan lain yang berhasil diidentifikasi di lapangan adalah tidak semua peserta didik memiliki buku pelajaran dan belum adanya lembar kegiatan peserta didik (LKPD) dalam proses pembelajaran fisika. Berdasarkan tuntutan dari kurikulum 2013 yang lebih menekankan pada peran serta aktif peserta didik dalam proses pembelajaran, maka diperlukan usaha untuk memotivasi peserta didik agar lebih berperan aktif lagi dalam mengonstruk pengetahuannya sendiri. Salah satunya melalui pemanfaatan Elektronik-Lembar Kegiatan Peserta Didik (E-LKPD) [1] berbasis Inkuiri Terbimbing.

LKPD elektronik adalah lembar latihan peserta didik yang dikerjakan secara digital dan dilakukan secara sistematis serta berkesinambungan selama jangka waktu tertentu [2][3]. Sementara itu, inkuiri terbimbing adalah interaksi antara peserta didik dengan material konkret (sumber belajar nyata) untuk menambah pengetahuan peserta didik tentang suatu konsep tertentu dengan memanfaatkan panduan dari guru untuk memecahkan masalah [4].

Pengembangan E-LKPD berbasis inkuiri terbimbing sebelumnya sudah pernah dilakukan oleh Ria Naulita Harahap (2020) dengan hasil bahwa pengembangan $E$-LKPD berbasis inkuiri terbimbing sangat baik digunakan dalam proses pembelajaran karena mampu meningkatkan kualitas belajar peserta didik melalui prosedur atau metode praktikum yang dapat dilakukan di rumah, kelas, maupun di laboratorium [5]. Hasil tersebut menunjukkan bahwa pengembangan $E$-LKPD berbasis inkuiri terbimbing dapat mengaktifkan peran peserta didik dalam proses pembelajaran. Dengan demikian, akan sesuai dengan permasalahan yang dihadapi oleh SMA N 1 Parittiga, yaitu peserta didik kurang aktif dalam mengikuti proses pembelajaran fisika karena belum memiliki buku referensi fisika untuk belajar mandiri di rumah selama masa pandemi Covid-19 dan proses pembelajaran fisika yang cenderung monoton.

\section{Metode Penelitian}

Penelitian ini termasuk dalam jenis research and development $(\mathrm{R} \& \mathrm{D})$ atau penelitian dan pengembangan. Penelitian dan pengembangan sering juga disebut dengan pengembangan berbasis penelitian. Penelitian dan pengembangan merupakan suatu proses yang digunakan untuk mengembangkan dan memvalidasi produkproduk pendidikan [6]. Tujuan dari penelitian dan pengembangan adalah untuk menghasilkan produk penelitian yang dapat digunakan untuk mengembangkan mutu pendidikan dan pembelajaran secara efektif [6]. 
Model penelitian dan pengembangan yang digunakan dalam penelitian ini mengadopsi model penelitian dan pengembangan yang diusulkan oleh Sugiyono. Model penelitian dan pengembangan menurut Sugiyono tersebut mengusulkan 10 (sepuluh) tahapan penelitian dan pengembangan, antara lain potensi dan masalah, mengumpulkan informasi, desain produk, validasi desain, perbaikan desain, uji coba produk, revisi produk, uji coba pemakaian, revisi produk, dan pembuatan produk masal [7]. Akan tetapi, karena keterbatasan waktu, biaya, dan kondisi pandemi Covid-19 yang masih melanda Indonesia pada umumnya, dan Kabupaten Bangka Barat pada khususnya, tahapan penelitian dan pengembangan ini hanya dibatasi sampai pada tahapan ke-lima. Kelima tahapan tersebut antara lain potensi dan masalah, mengumpulkan informasi, desain produk $E$-LKPD, validasi desain $E$-LKPD, dan perbaikan desain $E$-LKPD. Kelima tahapan tersebut selanjutnya diuraikan pada bagian ini. Penelitian ini dilakukan di SMA Negeri 1 Parittiga, Kabupaten Bangka Barat, Kepulauan Bangka Belitung pada semester gasal tahun ajaran 2020/2021.

Tahap pertama, tahap potensi dan masalah. Penelitian dan pengembangan dapat dilakukan karena adanya potensi dan masalah yang harus dicarikan solusinya, sehingga permasalahan tersebut dapat diselesaikan melalui solusi yang ditawarkan. Potensi merupakan segala sesuatu yang jika didayagunakan akan memiliki nilai tambah, sedangkan masalah merupakan ketidaksesuaian antara harapan dengan kenyataan yang sebenarnya. Kegiatan yang dilakukan pada tahap ini antara lain melakukan kegiatan observasi proses pembelajaran fisika secara daring sekaligus melakukan kegiatan wawancara dengan guru fisika di SMA Negeri 1 Parittiga untuk mengidentifikasi potensi yang terdapat di sekitar lingkungan sekolah dan juga menemukan masalah apa saja yang dihadapi oleh guru fisika dalam melakukan proses pembelajaran fisika secara daring selama masa pandemi Covid-19.

Tahap kedua, tahap mengumpulkan informasi. Kegiatan yang dilakukan pada tahap ini adalah mengumpulkan berbagai informasi yang dapat digunakan sebagai bahan untuk merencanakan produk tertentu dengan harapan produk yang akan dikembangkan tersebut dapat dimanfaatkan untuk mengatasi masalah yang dihadapi oleh institusi tempat penelitian. Metode yang digunakan untuk mengumpulkan informasi tersebut adalah metode literatur. Dalam metode literatur ini, peneliti mengkaji semua literatur yang akan digunakan sebagai bahan untuk pengembangan produk berupa $E$-LKPD. Literatur yang dikaji pada tahap pengumpulan informasi dalam penelitian dan pengembangan ini antara lain analisis Kurikulum 2013 (revisi 2016) dan bahan ajar (LKPD) fisika cetak yang dijual di pasaran.

Tahap ketiga, tahap desain produk $E$-LKPD. Tahap desain produk E-LKPD dilakukan setelah tahap pengumpulan informasi (data) disajikan secara faktual. Tahap desain produk E-LKPD dilaksanakan dengan melakukan perancangan awal desain produk $E$-LKPD yang akan dikembangkan. Dalam penelitian ini, produk yang dikembangkan adalah $E$-LKPD berbasis inkuiri terbimbing dengan harapan dapat meningkatkan produktivitas pendidikan guna membantu guru dan peserta didik dalam mengoptimalkan kegiatan pembelajaran yang saat ini dilakukan secara jarak jauh. Produk $E$-LKPD yang dikembangkan harus didesain sesuai dengan kebutuhan dan permasalahan serta potensi yang dimiliki oleh institusi tempat melakukan penelitian. Materi pembelajaran yang digunakan dalam pengembangan produk ini juga harus sesuai dengan kompetensi inti dan kompetensi dasar yang telah ada sehingga kegiatan pembelajaran yang dilakukan dapat mencapai tujuan yang diharapkan.

Tahap keempat, yaitu tahap validasi desain $E$-LKPD. Tahap ini juga disebut sebagai uji kelayakan produk. Uji kelayakan produk adalah suatu kegiatan yang dilakukan untuk memberikan penilaian kelayakan terhadap rancangan desain produk yang telah dibuat atau dikembangkan berdasarkan kriteria kelayakan produk yang telah ditetapkan sebelumnya. Kegiatan yang dilakukan pada tahap ini adalah melakukan penilaian kelayakan terhadap produk $E$-LKPD yang telah dikembangkan berdasarkan penilaian dari para validator, yaitu para ahli dan praktisi; serta berdasarkan respon atau uji keterbacaan dari peserta didik sebagai pengguna produk. Dalam penelitian ini, peneliti melibatkan dua orang ahli dalam bidang pendidikan fisika dan satu orang guru fisika sebagai praktisi.

Tahap kelima, yaitu tahap perbaikan desain E-LKPD. Tahap perbaikan desain $E$-LKPD dilakukan setelah tahap validasi desain $E$-LKPD atau uji kelayakan produk $E$-LKPD selesai dilakukan. Kegiatan yang dilakukan pada tahap ini adalah merevisi atau melakukan perbaikan terhadap desain $E$-LKPD yang telah dihasilkan pada tahap sebelumnya berdasarkan catatan, saran, dan masukan dari para ahli dan praktisi. Perbaikan desain $E$ LKPD dilakukan untuk mendapatkan produk E-LKPD yang siap digunakan untuk uji coba lapangan di sekolah. Oleh karena keterbatasan waktu, biaya, dan masa pandemi Covid-19 ini, kegiatan uji coba lapangan tidak dilakukan. Hasil yang diperoleh pada tahap ini berupa produk $E$-LKPD dengan kriteria penilaian kelayakannya. 
Subjek dalam penelitian ini terdiri atas dua orang ahli dalam bidang pendidikan fisika, satu orang guru fisika SMA N 1 Parittiga sebagai praktisi, dan 17 (tujuh belas) peserta didik sebagai responden. Objek dalam penelitian ini adalah E-LKPD Fisika Berbasis Inkuiri Terbimbing pada Materi Gerak Lurus untuk Peserta Didik Kelas X di SMA N 1 Partittiga.

Teknik pengumpulan data yang digunakan dalam penelitian dan pengembangan ini antara lain teknik observasi (pengamatan), teknik wawancara, dan teknik angket. Teknik observasi merupakan teknik pengumpulan data melalui proses pengamatan secara jeli, baik secara langsung maupun tidak langsung, terhadap objek pengamatan [7]. Dalam penelitian ini, teknik tersebut digunakan untuk mengumpulkan data tentang proses pembelajaran fisika secara daring dan luring yang dilakukan oleh guru selama masa pandemi Covid-19. Selanjutnya, teknik wawancara adalah teknik pengumpulan data yang dilakukan dengan interview atau wawancara atau tanya jawab secara mendalam terhadap informan [7]. Teknik tersebut digunakan untuk mengumpulkan data pada tahap potensi dan masalah melalui wawancara secara mendalam terhadap guru fisika SMA N 1 Parittiga tentang berbagai potensi dan masalah yang terdapat di ruang kelas, khususnya di kelas $\mathrm{X}$ IPA, selama proses pembelajaran fisika berlangsung, baik daring maupun luring. Sementara itu, teknik angket merupakan teknik pengumpulan data yang dilakukan dengan cara memberikan seperangkat pertanyaan atau pernyataan tertulis kepada responden untuk dijawab [7]. Dalam penelitian ini, teknik tersebut digunakan untuk menguji kelayakan produk $E$-LKPD melalui penilaian kelayakan $E$-LKPD dari para validator, yang terdiri atas ahli dan praktisi; serta untuk mendapatkan respon dari peserta didik terhadap $E$-LKPD yang dikembangkan dengan tujuan untuk menguji keterbacaan produk.

Instrumen pengumpul data yang digunakan dalam penelitian ini antara lain lembar pengamatan, pedoman wawancara, lembar penilaian kelayakan $E$-LKPD, dan angket respon peserta didik terhadap $E$-LKPD. Lembar pengamatan digunakan sebagai panduan untuk mengamati proses pembelajaran fisika, baik secara daring dan maupun secara luring, yang dilakukan oleh guru selama masa pandemi Covid-19. Pedoman wawancara digunakan sebagai pedoman dalam melakukan wawancara secara terstruktur dan mendalam terhadap guru fisika SMA N 1 Parittiga untuk mengungkap segala potensi dan permasalahan yang diduga muncul dalam proses pembelajaran fisika, baik secara luring maupun daring. Lembar penilaian kelayakan E-LKPD digunakan untuk menilai kelayakan $E$-LKPD yang dilakukan oleh validator, yaitu ahli dan praktisi. Angket respon peserta didik terhadap $E$-LKPD digunakan untuk mengukur keterbacaan $E$-LKPD berdasarkan respon dari peserta didik sebagai $u$ ser atau pengguna $E$-LKPD.

Teknik analisis data yang digunakan dalam penelitian ini antara lain indeks V Aiken dan teknik analisis data statistika deskriptif. Indeks V Aiken digunakan untuk menganalisis data penilaian kelayakan E-LKPD [8] [9] [10]. Aiken telah merumuskan indeks $\mathrm{V}$ Aiken untuk menghitung content-validity coefficient yang didasarkan pada hasil penilaian dari validator (ahli dan praktisi) sebanyak $n$ orang terhadap satu butir pernyataan tertentu dari segi sejauh mana butir tersebut mewakili konstruk yang diukur [11]. Persamaan indeks V Aiken dinyatakan sebagai:

$$
V=\frac{\sum S}{n(c-1)}
$$

\section{dengan}

$c$ : banyaknya kategori;

$r$ : skor penilaian yang diberikan oleh validator;

$n$ : banyaknya validator (dalam penelitian ini berjumlah 3 orang);

$S=r-l_{0}:$ (skor penilaian - skor terendah) untuk setiap butir; dan

$l_{0}$ : skor rating minimal (dalam hal ini adalah 1).

Indeks $\mathrm{V}$ Aiken tersebut selanjutnya diinterpretasikan menurut klasifikasi kategori indeks $\mathrm{V}$ Aiken seperti pada Tabel 1. 


\begin{tabular}{cc}
\hline Interval Indeks V Aiken & Klasifikasi Kategori \\
\hline $0 \leq \bar{V} \leq 0,33$ & Kurang \\
$0,34 \leq \bar{V} \leq 0,66$ & Cukup \\
$0,67 \leq \bar{V} \leq 1,00$ & Tinggi \\
\hline
\end{tabular}

Teknik analisis data statistika deskriptif digunakan untuk menganalisis data respon peserta didik terhadap $E$ LKPD yang telah dikembangkan. Langkah-langkah yang dilakukan dalam menganalisis data dengan menggunakan teknik tersebut antara lain:

a. Mengkonversi jawaban (kategori respon) yang diberikan oleh peserta didik pada angket respon peserta didik terhadap $E$-LKPD fisika untuk masing-masing butir pernyataan angket menjadi nilai kuantitatif dalam bentuk skor. Konversi tersebut mengikuti aturan pada Tabel 2.

Tabel 2. Konversi Kategori Respon Peserta Didik terhadap E-LKPD

\begin{tabular}{cc}
\hline Kategori Respon Peserta Didik terhadap $\boldsymbol{E}$-LKPD & Skor \\
\hline Sangat Setuju & 4 \\
Setuju & 3 \\
Tidak Setuju & 2 \\
Sangat Tidak Setuju & 1 \\
\hline
\end{tabular}

b. Menghitung persentase masing-masing kategori respon untuk setiap aspek dengan menggunakan persamaan [12][13]:

$$
P=\frac{f}{N} \times 100 \%
$$

dengan:

$P$ : angka persentase;

$f$ : frekuensi; dan

$N$ : jumlah peserta didik.

Hasil perhitungan persentase untuk setiap kategori pada angket respon peserta didik terhadap $E$-LKPD tersebut selanjutnya diklasifikasikan sesuai kategorinya menurut Tabel 3.

Tabel 3. Klasifikasi Kategori Respon Peserta Didik terhadap E-LKPD

\begin{tabular}{cc}
\hline Interval Persentase & Klasifikasi Kategori \\
\hline $81,26 \%-100 \%$ & Sangat Setuju \\
$62,51 \%-81,25 \%$ & Setuju \\
$43,76 \%-62,50 \%$ & Tidak Setuju \\
$25 \%-43,75 \%$ & Sangat Tidak Setuju \\
\hline
\end{tabular}

\section{Hasil Penelitian dan Pembahasan}

Hasil penelitian ini dideskripsikan berdasarkan tahapan prosedur penelitian dan pengembangan menurut Sugiyono yang terdiri atas 5 (lima) tahapan, antara lain potensi dan masalah, mengumpulkan informasi, desain produk $E$-LKPD, validasi desain $E$-LKPD, dan perbaikan desain $E$-LKPD.

Tahapan potensi dan masalah dilaksanakan dengan melakukan kegiatan observasi atau pengamatan terhadap proses pembelajaran fisika selama masa pandemi covid-19, baik yang diselenggarakan secara daring maupun luring; dan melakukan kegiatan wawancara secara mendalam dengan guru fisika SMA N 1 Parittiga. Hasil dari kegiatan observasi dan wawancara tersebut menunjukkan bahwa dalam proses pembelajaran fisika, peserta didik belum memiliki buku teks maupun modul mata pelajaran fisika. Sementara itu, guru hanya memiliki bahan ajar berupa buku teks fisika dan belum ditunjang dengan penggunaan LKPD fisika sebagai media belajar untuk memfasilitasi kegiatan-kegiatan yang harus dilakukan oleh peserta didik selama proses pembelajaran fisika berlangsung. Berdasarkan proses wawancara dengan guru fisika SMA N 1 Parittiga, guru 
juga menyampaikan bahwa dalam melakukan proses pembelajaran fisika selama ini, guru belum pernah menggunakan model pembelajaran inkuiri terbimbing. Guru hanya memfokuskan proses pembelajaran fisika pada penyampaian materi pembelajaran fisika sebanyak-banyaknya sehingga peserta didik menjadi pasif dalam mengikuti proses pembelajaran fisika, baik secara daring maupun secara luring. Hasil akhir pada tahap ini berupa keputusan untuk mengembangkan $E$-LKPD fisika berbasis inkuiri terbimbing.

Hasil yang diperoleh pada tahap kedua, tahap mengumpulkan informasi, yaitu berupa informasi mengenai bahan yang dapat digunakan untuk merencanakan pengembangan $E$-LKPD fisika berbasis inkuiri terbimbing. Bahan tersebut antara lain pedoman pelaksanaan kurikulum 2013, yang dioperasionalkan dalam bentuk standar nasional pendidikan, antara lain berupa standar isi dan standar proses; serta teori pendukung tentang model pembelajaran inkuiri terbimbing. Standar nasional pendidikan yang digunakan antara lain Permendikbud Nomor 21 Tahun 2016 tentang Standar Isi Pendidikan Dasar dan Menengah, Permendikbud Nomor 22 Tahun 2016 tentang Standar Proses Pendidikan Dasar dan Menengah, serta Permendikbud Nomor 24 Tahun 2016 tentang Kompetensi Inti (KI) dan Kompetensi Dasar (KD).

Berdasarkan potensi dan masalah pada tahap pertama, penelitian ini difokuskan pada pembelajaran fisika kelas X pada materi gerak lurus. Materi ini dipilih berdasarkan hasil analisis kebutuhan yang melibatkan guru dan peserta didik. Deskripsi KD untuk materi tersebut dikutip dari Permendikbud Nomor 24 Tahun 2016 tentang Kompetensi Inti (KI) dan Kompetensi Dasar (KD), yaitu KD 3.4 dan KD 4.4. Sementara itu, deskripsi KI untuk materi tersebut pada aspek sikap spiritual, sikap sosial, pengetahuan, dan keterampilan diadopsi dari Permendikbud Nomor 21 Tahun 2016 tentang Standar Isi Pendidikan Dasar dan Menengah. KI dan KD yang dipilih selanjutnya dielaborasi menjadi indikator pencapaian kompetensi (IPK) dan tujuan pembelajaran pada materi gerak lurus. Sintaks model pembelajaran inkuiri terbimbing diadopsi untuk menyajikan urutan kegiatan yang harus dilakukan oleh peserta didik sebagai pengguna $E$-LKPD yang dikembangkan. Sintaks model pembelajaran inkuiri terbimbing terdiri atas observasi untuk menemukan masalah, merumuskan masalah, mengajukan hipotesis, merancang percobaan, memperoleh hasil, analisis data, dan membuat kesimpulan.

Hasil yang diperoleh pada tahap ketiga, yaitu tahap desain produk $E$-LKPD, berupa draft atau rancangan $E$-LKPD Fisika Berbasis Inkuiri Terbimbing pada Materi Gerak Lurus untuk Peserta Didik Kelas X di SMA $\mathrm{N} 1$ Partittiga. Komponen $E$-LKPD yang dikembangkan antara lain halaman cover, perkenalan, kata pengantar, daftar isi, daftar gambar, daftar tabel, deskripsi $E$-LKPD, petunjuk penggunaan $E$-LKPD, standar isi, peta konsep, kegiatan LKPD, uji kompetensi, daftar pustaka, dan profil penulis.

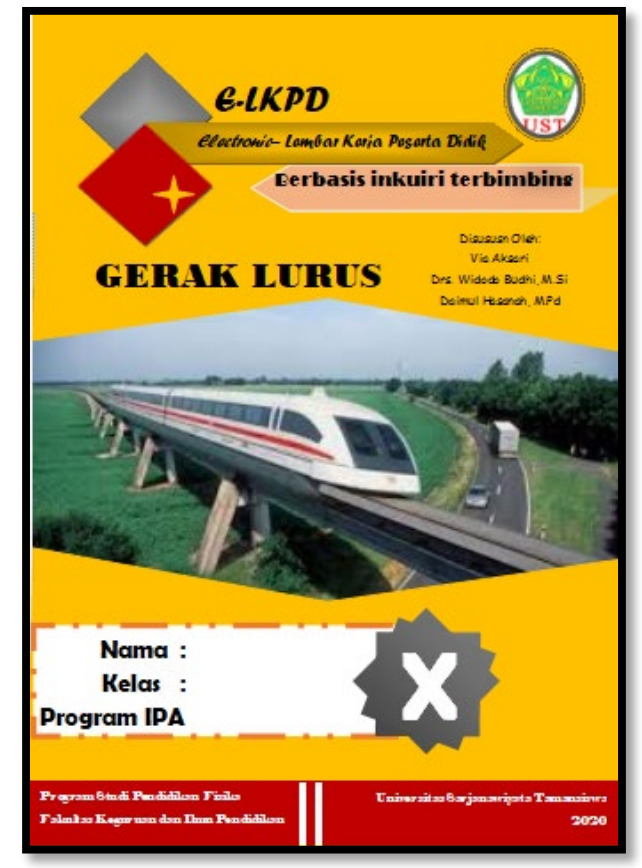

Gambar 1. Cover depan E-LKPD

Halaman cover dirancang dengan menampilkan gambar yang termasuk dalam contoh gerak lurus, dengan memuat judul dari E-LKPD yang dikembangkan. Selain itu, pada halaman cover juga tercantum nama 
pengarang serta logo universitas. Dengan memerhatikan keharmonian komposisi warna sehingga diperoleh cover yang dapat menarik perhatian peserta didik.

$E$-LKPD yang dikembangkan dalam bentuk pdf yang memiliki empat subbab di dalamnya, dengan setiap subbab terdapat penjelasan materi yang akan dipelajari dan dilengkapi dengan link video yang dapat dibuka oleh peserta didik, sehingga kegiatan pembelajaran yang dilakukan lebih interaktif dan menarik bagi peserta didik. Dalam melakukan kegiatan praktikum peserta didik akan dituntun dengan melakukan praktikum secara online menggunakan aplikasi Phet, yaitu aplikasi simulasi eksperimen sains yang dikembangkan secara interaktif. Aplikasi ini dapat diakses oleh peserta didik melalui link yang terdapat dalam $E$-LKPD.
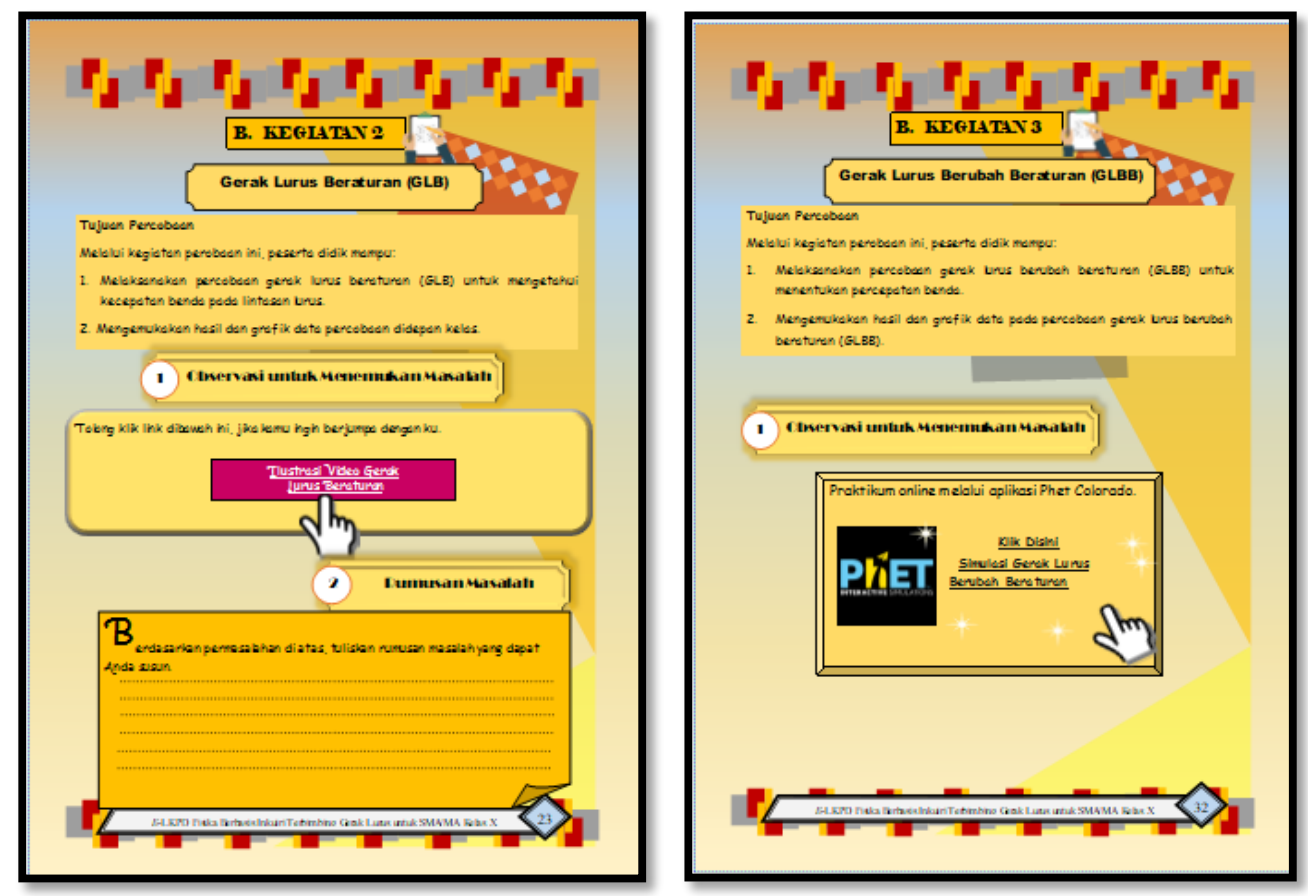

Gambar 2. Isi LKPD

Pengembangan $E$-LKPD fisika dengan menggunakan format pdf akan memiliki beberapa keuntungan misalnya tidak membutuhkan aplikasi tambahan untuk dapat mengakses $E$-LKPD , tidak perlu membutuhkan jarinagn internet jika ingin membuka $E$-LKPD dengan format pdf. Selain itu, $E$-LKPD fisika yang dikembangkan dengan mencantumkan link dari video pembelajaran dapat di akses langsung tanpa harus mengubah dalam bentuk dokumen lainnya. Format pdf juga memberikan kemudahan dalam membuka $E$ LKPD karena format ini dapat di buka melalui komputer atau smarphone manapun tanpa mengalami perubahan data atau isi $E$-LKPD, ukuran file $E$-LKPD format pdf yang kecil memungkin peserta didik untuk menyimpan file $E$-LKPD tanpa membutuhkan memori yang besar. Selain itu peserta didik dapat menghindari perubahan data pada $E$-LKPD yang telah diisi dengan melakukan setting password sehingga tidak dapat diubah secara sembarangan ataupun dibuka oleh siapapun secara tidak sengaja.

Hasil yang diperoleh pada tahap keempat, tahap validasi desain $E$-LKPD, yaitu berupa penilaian kelayakan $E$-LKPD dari para validator dan hasil angket respon peserta didik terhadap $E$-LKPD yang telah dikembangkan. Selain itu, juga diperoleh catatan, saran, dan masukan dari para validator sebagai bahan untuk perbaikan $E$-LKPD. Hasil penilaian kelayakan $E$-LKPD dari para validator, yaitu ahli dan praktisi, selanjutnya dianalisis dengan menggunakan indeks V Aiken seperti yang disajikan pada Tabel 4.

Tabel 4. Hasil Penilaian Kelayakan E-LKPD oleh Validator

\begin{tabular}{ccc}
\hline Komponen Penilaian Kelayakan $\boldsymbol{E}$-LKPD & Indeks V Aiken & Kategori \\
\hline Kelayakan isi & 0,83 & Tinggi \\
Kebahasaan & 0,93 & Tinggi \\
Penyajian & 0,96 & Tinggi \\
Rerata & $\mathbf{0 , 9 1}$ & Tinggi \\
\hline
\end{tabular}


Berdasarkan Tabel 4, hasil penilaian kelayakan $E$-LKPD yang telah dikembangkan memiliki nilai rerata indeks V Aiken sebesar 0,91. Jika dikonfirmasikan ke dalam Tabel 1 maka rerata indeks V Aiken tersebut termasuk dalam kategori Tinggi. Dengan demikian, dapat disimpulkan bahwa E-LKPD Fisika Berbasis Inkuiri Terbimbing pada Materi Gerak Lurus untuk Peserta Didik Kelas X di SMA N 1 Parittiga dinyatakan layak digunakan sebagai salah satu bahan ajar dalam proses pembelajaran fisika di SMA N 1 Parittiga, dengan kategori tinggi.

Hasil angket respon peserta didik terhadap $E$-LKPD yang telah dikembangkan selanjutnya dianalisis dengan menggunakan statistika deskriptif seperti yang ditampilkan pada Tabel 5.

Tabel 5. Hasil Analisis Data Angket Respon Peserta Didik terhadap E-LKPD

\begin{tabular}{|c|c|c|c|c|}
\hline \multirow{2}{*}{ Komponen } & \multicolumn{4}{|c|}{ Persentase (\%) } \\
\hline & Sangat Setuju & Setuju & Tidak Setuju & Sangat Tidak Setuju \\
\hline Kemudahan Memahami Isi. & 72 & 28 & 0 & 0 \\
\hline $\begin{array}{l}\text { Penggunaan Bahasa yang } \\
\text { Mudah Dipahami. }\end{array}$ & 53 & 47 & 0 & 0 \\
\hline Penyajian $E$-LKPD menarik. & 79 & 21 & 0 & 0 \\
\hline Rata-rata & 68 & 32 & $\mathbf{0}$ & $\mathbf{0}$ \\
\hline
\end{tabular}

Berdasarkan Tabel 5, persentase rata-rata peserta didik yang memberikan respon Sangat Setuju sebanyak 68\% sedangkan persentase rata-rata peserta didik yang memberikan respon Setuju sebanyak 32\%. Dengan demikian, dapat dinyatakan bahwa respon peserta didik terhadap E-LKPD Fisika Berbasis Inkuiri Terbimbing pada Materi Gerak Lurus untuk Peserta Didik Kelas X di SMA N 1 Parittiga termasuk dalam kategori Setuju.

Tahap kelima, yaitu tahap perbaikan desain $E$-LKPD, diperoleh hasil perbaikan draft E-LKPD fisika berbasis inkuiri terbimbing menjadi prototipe $E$-LKPD. Perbaikan tersebut dilakukan berdasarkan catatan, saran, dan masukan dari para validator pada saat penilaian kelayakan $E$-LKPD di tahap keempat. Revisi desain $E$-LKPD dilakukan sebagai langkah untuk menyempurnakan draft E-LKPD fisika yang dikembangkan. Adapun catatan, saran, dan masukan yang diberikan oleh validator terhadap draft E-LKPD fisika berbasis inkuiri terbimbing antara lain: perbaikan lay-out pada peta konsep, perbaikan penulisan besaran yang termasuk besaran vektor dan skalar, serta perbaikan konsep materi.

Hasil penelitian ini selaras dengan beberapa hasil penelitian tentang penelitian dan pengembangan perangkat pembelajaran fisika dalam bentuk LKPD fisika berbasis inkuiri terbimbing. Salah satu diantaranya, beberapa penelitian yang telah dilakukan menunjukkan bahwa LKPD dengan pendekatan guided inquiry layak digunakan sebagai bahan ajar fisika pada materi Suhu dan Kalor [14][15][16]. Penelitian lain dilakukan oleh Chodijah dengan hasil bahwa salah satu perangkat pembelajaran yang telah dikembangkan, memiliki kriteria kualitas dengan kategori sangat valid, sangat praktis, dan sangat efektif [17]. LKPD berbasis inkuiri terbimbing mampu meningkatkan keterampilan berpikir kritis dan hasil belajar peserta didik [18][19]. Penelitian lain menyebutkan bahwa LKPD berbasis inkuiri terbimbing mampu meningkatkan keterampilan berpikir kritis dan penguasaan konsep peserta didik [20]. Salah satu alasan yang mendukung hasil penelitian tersebut didasarkan pada sintaks model inkuiri terbimbing yang terdiri atas identifikasi masalah dan melakukan pengamatan, mengajukan pertanyaan, merencanakan penyelidikan, mengumpulkan data atau informasi dan melaksanakan penyelidikan, menganalisis data, membuat kesimpulan, dan mengkomunikasikan hasil [21]. Selain itu, model inkuiri terbimbing mampu memberikan kesempatan kepada peserta didik untuk bekerja merumuskan prosedur, menganalisis hasil, dan mengambil kesimpulan secara mandiri. Guru hanya berperan sebagai fasilitator dalam hal menentukan topik, pertanyaan, dan bahan penunjang. Berdasarkan karakteristiknya, model inkuiri terbimbing merupakan suatu model pembelajaran yang difokuskan pada proses berpikir dengan membangun pengalaman oleh keterlibatan peserta didik secara aktif dalam proses pembelajaran [17]. Peserta didik dituntut untuk belajar dengan mengonstruk pengetahuan mereka sendiri berdasarkan pengalaman-pengalaman dan segala sesuatu yang telah mereka ketahui.

\section{Kesimpulan}

Telah dihasilkan E-LKPD Fisika Berbasis Inkuiri Terbimbing pada Materi Gerak Lurus untuk Peserta Didik Kelas X SMAN 1 Parittiga, Kabupaten Bangka Barat, Kepulauan Bangka Belitung dengan menggunakan 5 (lima) tahapan prosedur dari 10 (sepuluh) tahapan prosedur penelitian dan pengembangan yang diusulkan oleh 
Sugiyono, antara lain: potensi dan masalah, mengumpulkan informasi, desain produk $E$-LKPD, validasi desain $E$-LKPD, dan perbaikan desain $E$-LKPD. Hasil analisis data uji kelayakan $E$-LKPD menunjukkan bahwa $E$ LKPD yang telah dikembangkan mendapatkan penilaian kelayakan $E$-LKPD dari para validator (ahli dan praktisi) dengan indeks $\mathrm{V}$ Aiken sebesar 0,91 sehingga memenuhi kriteria kelayakan dengan kategori tinggi. Respon peserta didik terhadap E-LKPD Fisika Berbasis Inkuiri Terbimbing pada Materi Gerak Lurus untuk Peserta Didik Kelas X di SMA N 1 Parittiga termasuk dalam kategori positif.

Penelitian ini memiliki keterbatasan karena peneliti hanya mengambil 5 tahapan dari 10 tahapan pengembangan yang tersedia. Namun demikian, proses pengembangan dilakukan sesuai kaidah di setiap tahapan. Peneliti merekomendasikan dilakukan penelitian lanjutan jika kondisi pandemi telah membaik guna melengkapi hasil perbaikan produk di tahapan-tahapan pengembangan berikutnya

\section{Ucapan Terimakasih}

Pelaksanaan penelitian ini berdasarkan ijin dari Fakultas Keguruan dan Ilmu Pendidikan (FKIP) Universitas Sarjanawiyata Tamansiswa Yogyakarta dan SMA N 1 Parittiga, Kabupaten Bangka Barat, Kepulauan Bangka Belitung. Oleh karena itu, peneliti dengan penuh kerendahan hati mengucapkan terima kasih atas segala dukungan dan segala bentuk yang dapat memberikan bantuan bagi berjalannya penelitian ini.

\section{Kepustakaan}

[1] E. Y. Awe and M. I. Ende, "Pengembangan Lembar Kerja Siswa Elektronik Bermuatan Multimedia Untuk Meningkatkan Kemampuan Kognitif Siswa Pada Tema Daerah Tempat Tinggalku Pada Siswa Kelas IV SDI Rutosoro Di Kabupaten Ngada," J. DIDIKA Wahana Ilm. Pendidik. Dasar, vol. V, no. 2, pp. 48-61, 2019.

[2] Ramlawati, Liliasari, M. A. Martoprawiro, and A. R. Wulan, "The Effect of Electronic Portfolio Assessment Model to Increase of Students' Generic Science Skills in Practical Inorganic Chemistry," J. Educ. Learn., vol. 8, no. 3, pp. 179-186, 2014.

[3] F. N. Sari, Nurhayati, and S. Soetopo, "Pengembangan Lembar Kerja Peserta Didik (LKPD) Elektronik Teks Cerita Pendek Berbasis Budaya Lokal,” in Seminar Nasional Pendidikan Bahasa Indonesia, 2017, pp. 83-98.

[4] I. Bilgin, "The effects of guided inquiry instruction incorporating a cooperative learning approach on university students' achievement of acid and bases concepts and attitude toward guided inquiry instruction," Sci. Res. Essay, vol. 4, no. 10, pp. 1038-1046, 2009.

[5] R. N. Harahap, "Pengembangan e-LKPD Berbasis Inkuiri Terbimbing pada Materi Koloid Kelas XI MIA SMAN 7 Kota Jambi." Repository Universitas Jambi, Jambi, 2020.

[6] A. Ghufron, "Pendekatan Penelitian dan Pengembangan (R\&D) di Bidang Pendidikan dan Pembelajaran," Yogyakarta: FIP UNY, 2011.

[7] Sugiyono, Metode Penelitian Pendidikan (Pendekatan Kuantitatif, Kualitatif, dan R\&D). Bandung: Penerbit Alfabeta, 2013.

[8] O. J. Jegede and G. S. Aikenhead, "Transcending cultural borders: Implications for science teaching," Int. J. Phytoremediation, vol. 17, no. 1, pp. 45-66, 1999, doi: 10.1080/0263514990170104.

[9] L. R. Aiken, "Three Coefficients for Analyzing The Reliability and Validity of Ratings," Educ. Psychol. Meas., vol. 45, pp. 131-, 1985.

[10] L. R. Aiken, "Content Validity and Reliability of Single Items or Questionnaires," Educ. Psychol. Meas., vol. 40, p. 955, 1980, doi: 10.1177/001316448004000419.

[11] S. Azwar, Reliabilitas dan Validitas, Edisi 4. Yogyakarta: Pustaka Pelajar, 2012.

[12] N. A. Himawan, Jumadi, and E. Purwanto, "Identifikasi Kemampuan Penalaran Siswa Kelas XI di MAN 4 Bantul pada Suhu dan Kalor," Edusains, vol. 12, no. 1, pp. 30-37, 2020.

[13] S. Ramdhani, "Analisis Kemampuan Penalaran Analogis Mahasiswa Pendidikan Matematika dalam Persamaan Diferensial Ordo Satu,” J. Prism. Univ. Suryakancana, vol. VI, no. 2, pp. 162-172, 2017.

[14] P. Rahayu, Sriyono, and N. Ngazizah, "Pengembangan Worksheet dengan Pendekatan Guided Inquiry pada Pokok Bahasan Suhu dan Kalor untuk Mengoptimalkan Domain Proses Sains Siswa Kelas X SMA N 11 Purworejo Tahun Pelajaran 2012/2013," Radiasi, vol. 3, no. 1, pp. 78-82, 2013.

[15] S. Latifah, E. Setiawati, and A. Basith, "Pengembangan Lembar Kerja Peserta Didik (LKPD) Berorientasi NilaiNilai Agama Islam Melalui Pendekatan Inkuiri Terbimbing pada Materi Suhu dan Kalor,” J. Ilm. Pendidik. Fis. Al- 
BiRuNi, vol. 5, no. 1, pp. 43-51, 2016, doi: 10.24042/jpifalbiruni.v5i1.104.

[16] Y. Astuti and B. Setiawan, "Pengembangan Lembar Kerja Siswa (LKS) Berbasis Pendekatan Inkuiri Terbimbing dalam Pembelajaran Kooperatif pada Materi Kalor," vol. 2, no. 1, pp. 88-92, 2013.

[17] S. Chodijah, A. Fauzi, and R. Wulan, "Pengembangan Perangkat Pembelajaran Fisika Menggunakan Model Guided Inquiry yang Dilengkapi Penilaian Portofolio pada Materi Gerak Melingkar,” J. Penelit. Pembelajaran Fis., vol. 1, pp. 1-19, 2012.

[18] M. Firdaus and I. Wilujeng, "Pengembangan LKPD Inkuiri Terbimbing untuk Meningkatkan Keterampilan Berpikir Kritis dan Hasil Belajar Peserta Didik.," J. Inov. Pendidik. IPA, vol. 4, no. 1, pp. 26-40, 2018.

[19] N. Annafi, Ashadi, and S. Mulyani, "Pengembangan Lembar Kegiatan Peserta Didik Berbasis Inkuiri Terbimbing pada Materi Termokimia Kelas XI SMA/MA,” J. Inkuiri, vol. 4, no. 3, pp. 21-28, 2015.

[20] E. Y. S. Asmawati, "Lembar Kerja Siswa (LKS) Menggunakan Model Guided Inquiry untuk Meningkatkan Keterampilan Berpikir Kritis dan Penguasaan Konsep Siswa,” J. Pendidik. Fis. Univ. Muhammadiyah Metro, vol. III, no. 1, pp. 1-16, 2015.

[21] Nurdyansyah and E. F. Fahyuni, Inovasi Model Pembelajaran. Sidoarjo: Nizamial Learning Center, 2016. 